\title{
Genetic evidence to exclude the androgen receptor- polyglutamine associated coactivator, ARA-24, as a cause of male undermasculinisation
}

\author{
N P Mongan, H N Lim and I A Hughes \\ University Department of Paediatrics, Addenbrooke's Hospital, University of Cambridge, Cambridge CB2 2QQ, UK \\ (Correspondence should be addressed to N P Mongan who is now at Department of Pharmacology, Weill Medical College of Cornell University, \\ 1300 York Avenue, New York, NY 10021, USA; Email: n.p.e.mongan.95@cantab.net)
}

Defects in the development and function of the male reproductive system are common (1). Abnormalities range from completely female external genitalia to isolated hypospadias or infertility (1). The underlying basis of the abnormalities is mostly attributable to a reduction in androgen (testosterone or 5- $\alpha$-dihydrotestoterone (DHT)) action, referred to as undermasculinisation. In some cases of undermasculinisation, abnormalities of androgen production have been demonstrated, and in others there are identifiable defects in the function of the androgen receptor (AR), which mediates the effect of the androgens (2).

The AR is a member of the nuclear hormone receptor superfamily (3). It contains three functional domains: an N-terminal ligand-independent activation function, a central DNA-binding domain, and the C-terminus, which includes residues crucial for androgen binding, receptor dimerisation and transactivation. The N-terminal domain includes a polymorphic region of 11-31 glutamine repeats $\left(\mathrm{AR}[\mathrm{Gln}]_{\mathrm{n}}\right)$ (4). Mutations in the AR have been shown to cause complete genital undermasculinisation (complete androgen insensitivity syndrome, CAIS) and the less clinically severe partial androgen insensitivity syndrome (PAIS). Although PAIS is the most common diagnosis of undermasculinised genitalia in 46XY males (1), for most cases there is no identifiable cause (2).

There is evidence that expansions of the AR polyglutamine repeat contribute to undermasculinisation. Excessively long $\mathrm{AR}[\mathrm{Gln}]_{n}$ tracts $(40-62$ repeats) occur in the rare X-linked spinal and bulbar muscular atrophy (SBMA), which often has the associated features of male infertility, testicular atrophy and gynaecomastia (5). Smaller increases in polyglutamine repeat length (remaining within the normal range) may contribute to moderate to severe undermasculinised male genitalia (6). In the latter disorder, $\mathrm{AR}[\mathrm{Gln}]_{n}$ length is clearly affecting at least one other factor that is sensitive to its length and is therefore probably interacting directly with this region of the AR. Therefore, in the many patients with undermasculinisation who have no identifiable defect in either androgen production or the AR, it is necessary to investigate other factors that interact with the AR.
The recruitment of multiple coactivator proteins is essential to enhance AR-mediated androgen-dependent transactivation (7). There is evidence that one of these AR coactivators, ARA-24 (8) (also known as RAN) can contribute to reduced AR function. It was demonstrated that expansion of the AR[Gln $]_{n}$ tract length diminishes the physical interaction of ARA-24 with the AR, resulting in decreased coactivation (8). Consequently, mutations or polymorphisms that reduce the action, interaction, or both, of ARA-24 with the AR would be expected to contribute to reduced androgendependent transactivation and lead to undermasculinisation. There is now compelling evidence that some cases of undermasculinisation may be due to disruption of coactivator function $(9,10)$. Therefore the aim of this study was to investigate whether mutations or polymorphisms within the coding region of ARA-24 are a common cause of undermasculinised genitalia in 46XY males with normal androgen biosynthesis, normal AR-androgen binding characteristics and $\mathrm{AR}[\mathrm{Gln}]_{n}$ within the normal range.

The patient group was composed of 25 men with normal 46XY karyotypes (Table 1). All patients' samples were obtained from the Cambridge Intersex Database (1). Local ethics committee approval was obtained for the use of patient samples as part of a sexual development disorders research programme. All patients had a normal gonadotrophin profile and a testosterone and DHT response to human chorionic gonadotrophin stimulation consistent with a diagnosis of androgen insensitivity syndrome. Furthermore, all patients had AR-binding studies performed on genital skin fibroblasts and all had normal receptor androgen affinity and binding capacity (1) as measured using methods described previously (11). AR[Gln $]_{n}$ was determined as described previously (6) or by direct sequencing.

RNA was extracted from the primary genital skin fibroblast cultures of patients' skin biopsies using either the Chomczynski method (12) or the Trizol reagent (Life Technologies, Paisley, Scotland, UK). cDNA was synthesised using standard methods (Superscript II, Life Technologies). The polymerase chain reaction (PCR) was used to amplify the coding region of the ARA-24 transcript, using primer sequences of $5^{\prime}$-ggcgcttctggaaggaacgccg-3' 
Table 1 Patients' clinical features. All patients' samples were obtained from the Cambridge Intersex Database (1). Androgen receptor binding studies that measured receptor affinity $\left(K_{\mathrm{d}}\right)$ $\left(\times 10^{-10} \mathrm{~mol} / \mathrm{l}\right)$ and binding capacity $\left(B_{\max }\right)\left(\times 10^{-18} / \mathrm{mg} \mathrm{DNA}\right)$, were performed on genital skin fibroblast cultures as described elsewhere (11). Exons $\mathrm{B}-\mathrm{H}$ of the $A R$ gene, where $>90 \%$ of PAIS-causing mutations are found (www.mcgill.ca/androgendb), were screened by direct sequencing. AR[GIn $]_{n}$ was determined as described previously (7) or by direct sequencing. Physical features of undermasculinisation are: UF, unfused scrotum; BS, bifid scrotum; MP, micropenis; PSH, perino-scrotal hypospadias; $\mathrm{PH}$, perineal hypospadias; $\mathrm{GH}$, glandular hypospadias.

\begin{tabular}{|c|c|c|c|c|c|}
\hline \multirow{2}{*}{$\begin{array}{l}\text { Patient } \\
\text { No. }\end{array}$} & \multirow{2}{*}{$\begin{array}{l}\text { Clinical } \\
\text { feature }\end{array}$} & \multicolumn{2}{|c|}{ AR binding } & \multirow{2}{*}{$\begin{array}{c}A R \\
\text { exon }\end{array}$} & \multirow[b]{2}{*}{$\mathrm{AR}[\mathrm{GIn}]_{r}$} \\
\hline & & $K_{\mathrm{d}}$ & $B_{\max }$ & & \\
\hline 1 & $\mathrm{PH}, \mathrm{MP}$ & 1.1 & 593 & $\mathrm{~B}-\mathrm{H}$ & 25 \\
\hline 2 & $\mathrm{PH}, \mathrm{MP}$ & 1.5 & 902 & $\mathrm{~B}-\mathrm{H}$ & 30 \\
\hline 3 & $\mathrm{PH}, \mathrm{BS}$ & 0.7 & 1747 & $\mathrm{~B}-\mathrm{H}$ & 25 \\
\hline 4 & MP, BS & 0.9 & 1780 & $\mathrm{~B}-\mathrm{H}$ & 22 \\
\hline 5 & BS, PSH & 0.9 & 775 & $\mathrm{~B}-\mathrm{H}$ & 23 \\
\hline 6 & $\mathrm{PH}, \mathrm{MP}$ & 1.2 & 1101 & $\mathrm{~B}-\mathrm{H}$ & 26 \\
\hline 7 & BS, PSH & 1.1 & 540 & $\mathrm{~B}-\mathrm{H}$ & 24 \\
\hline 8 & BS, PSH, MP & 1.0 & 308 & $\mathrm{~B}-\mathrm{H}$ & 20 \\
\hline 9 & BS, PSH & 1.0 & 619 & $\mathrm{~B}-\mathrm{H}$ & 27 \\
\hline 10 & BS, PSH & 1.6 & 1289 & $\mathrm{~B}-\mathrm{H}$ & 19 \\
\hline 11 & $\mathrm{PH}$ & 1.4 & 989 & $\mathrm{~B}-\mathrm{H}$ & 24 \\
\hline 12 & PSH, MP & 1.8 & 858 & $\mathrm{~B}-\mathrm{H}$ & 29 \\
\hline 13 & $\mathrm{MP}, \mathrm{PH}$ & 1.4 & 844 & $\mathrm{~B}-\mathrm{H}$ & 28 \\
\hline 14 & PSH & 0.8 & 551 & $\mathrm{~B}-\mathrm{H}$ & 27 \\
\hline 15 & $\mathrm{MP}, \mathrm{GH}$ & 0.9 & 752 & $\mathrm{~B}-\mathrm{H}$ & 22 \\
\hline 16 & $\mathrm{GH}$ & 1.9 & 1268 & $\mathrm{~B}-\mathrm{H}$ & 25 \\
\hline 17 & UF, PH & 1.3 & 774 & $\mathrm{~B}-\mathrm{H}$ & 25 \\
\hline 18 & UF, $\mathrm{PH}, \mathrm{MP}$ & 0.9 & 914 & $\mathrm{~B}-\mathrm{H}$ & 20 \\
\hline 19 & UF, PH & 2.5 & 1186 & $\mathrm{~B}-\mathrm{H}$ & 31 \\
\hline 20 & $\mathrm{PH}, \mathrm{MP}$ & 0.6 & 428 & $\mathrm{~B}-\mathrm{H}$ & 22 \\
\hline 21 & $\mathrm{PH}, \mathrm{MP}$ & 0.9 & 137 & $\mathrm{~B}-\mathrm{H}$ & 27 \\
\hline 22 & UF, PH & 1.1 & 919 & $\mathrm{~B}-\mathrm{H}$ & 26 \\
\hline 23 & $\mathrm{BS}, \mathrm{PH}$ & 1.2 & 493 & $\mathrm{~B}-\mathrm{H}$ & 23 \\
\hline 24 & UF, PH, MP & 0.9 & 416 & $\mathrm{~B}-\mathrm{H}$ & 21 \\
\hline 25 & MP & 2.9 & 320 & $\mathrm{~B}-\mathrm{H}$ & 25 \\
\hline
\end{tabular}

(forward) and $5^{\prime}$ - gcaccgctgacatcacaggacag- $3^{\prime}$ (reverse). All products were sequenced directly in both directions using automated sequencing techniques (Applied BioSystems, Warrington, UK) and were consistent with the published sequence of ARA-24 (GenBank accession No. AF052578).

The coding region of ARA-24 was successfully screened by direct sequencing of RT-PCR products, thereby excluding absence (but not partial reduction) of ARA-24 expression in the target tissue as the cause of undermasculinisation. In addition, this method was able to exclude genetic rearrangement or exonic deletions as causes of ARA-24 inactivation in undermasculinised men. Significantly, no mutations or polymorphisms were found in ARA-24 of any of the 25 patients.

More than 40 proteins have been shown to interact functionally with the AR in vitro (full references of all AR-interacting proteins are provided at the excellent AR database at http://www.mcgill.ca/androgendb). Mouse genetic models reveal that disruption of a general nuclear receptor coactivator (SRC-1) can result in multiple nuclear hormone resistance syndromes (13). Furthermore, disruption of AR-coactivator interactions has been shown to cause reduced male fertility, Kennedy's syndrome (8) and PAIS (14). ARA-24 is a member of a subset of coactivators known to be crucial for optimal AR functioning (7) and thus disruption of its functions could potentially contribute to undermasculinisation (15). However, we have shown, by the absence of ARA-24 mutations in 25 well-characterised undermasculinised men with apparently normal androgen biosynthesis, AR, AR[Gln $]_{n}$ and AR binding characteristics, that ARA-24 mutations are not a common cause of moderate to severe undermasculinisation.

Longer $\mathrm{AR}[\mathrm{Gln}]_{\mathrm{n}}$ regions appear to contribute to undermasculinisation by a multifactorial aetiology (16). The apparent sensitivity of ARA-24 activity to $\mathrm{AR}[\mathrm{Gln}]_{n}$ length and its direct interaction with this region of the AR (8) suggest that it is a good candidate for involvement in undermasculinisation. It has yet to be determined whether a reduction in ARA-24 activity is the mechanism by which longer $\mathrm{AR}[\mathrm{Gln}]_{n}$ contributes to genital abnormalities. However, this study was also able to exclude both ARA-24 protein and nucleotide polymorphisms as factors contributing directly to the multifactorial cause of male undermasculinisation. This does not exclude the possible involvement of ARA-24 mutations in other disorders of abnormal androgen action which have yet to be studied, including prostate cancer or testicular maldescent. Future clinical studies may wish to examine these phenotypes, particularly when there is further in vitro evidence to delineate ARA-24 function.

\section{Acknowledgements}

The authors thank all the clinicians who sent samples and details to the Cambridge Intersex Database. This research was supported by the Birth Defects Foundation (N P M, H N L), an Overseas Student's Award (H N L) and the EU BioMed Program.

\section{References}

1 Ahmed SF, Cheng A, Dovey L, Hawkins JR, Martin H, Rowland MJ et al. Phenotypic features, androgen receptor binding and mutation analysis in 278 clinical cases reported as androgen insensitivity syndrome. Journal of Clinical Endocrinology and Metabolism $2000 \mathbf{8 5} 658-665$.

2 Batch JA, William DM, Davies HR, Brown BD, Evans BAJ, Hughes IA et al. Androgen receptor gene mutations identified by SSCP in 14 subjects with androgen insensitivity. Human Molecular Genetics $19921497-503$.

3 Brinkmann AO, Blok LJ, de Ruiter PE, Doesburg P, Steketee K, Berrevoets CA et al. Mechanisms of androgen receptor activation and function. Journal of Steroid Biochemistry and Molecular Biology $199969307-313$.

4 Edwards A, Hammond HA, Jin L, Caskey CT \& Chakraborty R. Genetic variation in five trimeric and tetrameric tandem repeat loci in four human population groups. Genomics $1992 \mathbf{1 2}$ $241-253$. 
5 La Spada AR, Roling D, Harding AE, Warner CL, Spigel R, Hausmanowa-Petrusewicz I et al. Meiotic stability and genotypephenotype correlation of the trinucleotide repeat in X-linked spinal and bulbar muscular atrophy. Nature Genetics 19922 301-304.

6 Lim HN, Chen H, McBride S, Dunning AM, Nixon RM, Hughes IA et al. Longer polyglutamine tracts in the androgen receptor are associated with moderate to severe undermasculinized genitalia in XY males. Human Molecular Genetics 20009 829-834.

7 McKenna NJ, Lanz RB \& O'Malley BW. Nuclear receptor coregulators: cellular and molecular biology. Endocrine Reviews 199920 $321-344$.

8 Hsiao PW, Lin DL, Nakao R \& Chang C. The linkage of the Kennedy's neuron disease to ARA-24, the first identified androgen receptor polyglutamine region-associated coactivator. Journal of Biological Chemistry $199927420229-20234$.

9 Adachi M, Takayanagi R, Tomura A, Imasaki K, Kato S, Goto K et al. Androgen insensitivity syndrome as a possible coactivator disease. New England Journal of Medicine 2000343 856-862.

10 New MI, Nimkarn S, Brandon DD, Cunningham-Rundles S, Wilson RC, Newfield RS et al. Resistance to several steroids in two sisters. Journal of Clinical Endocrinology and Metabolism 1999 84 4454-4464.

11 Hughes IA \& Evans BAJ. Androgen insensitivity in forty-nine patients: classification based on clinical and androgen receptor phenotypes. Hormone Research 198728 25-29.
12 Chomczynski P \& Saachi N. Single step method of RNA isolation by acid guanidinium thiocyanate-phenol-chloroform extraction. Analytical Biochemistry $1987 \mathbf{1 6 2} 156-159$.

13 Xu JM, Qiu YH, DeMayo FJ, Tsai SY, Tsai MJ \& O’Malley BW. Partial hormone resistance in mice with disruption of the steroid receptor coactivator-1 (SRC-1) gene. Science $19982791922-1925$.

14 Ghadessy FJ, Lim J, Abdullah AR, Panet-Raymond V, Choo CK, Lumbroso $\mathrm{R}$ et al. Oligospermic infertility associated with an androgen receptor mutation that disrupts interdomain and coactivator (TIF2) interactions. Journal of Clinical Investigation $19991031517-1525$.

15 Lim HN, Hawkins JR \& Hughes IA. Genetic evidence to exclude the androgen receptor cofactor ARA-70 (NCOA4) as a candidate gene for the causation of undermasculinised genitalia. Clinical Genetics $200159284-286$.

16 Lim HN, Nixon RM, Chen H, Hughes IA \& Hawkins JR. Evidence that longer androgen receptor polyglutamine repeats are a causal factor for genital abnormalities. Journal of Clinical Endocrinology and Metabolism $20018 \mathbf{8 6} 3207-3210$.

Received 21 August 2001

Accepted 22 August 2001 